REPUBLICS OF THE NEW WORLD 



\title{
Republics of the New World
}

\author{
THE REVOLUTIONARY \\ POLITICAL EXPERIMENT \\ IN NINETEENTH-CENTURY \\ LATIN AMERICA
}

pan- 2 weseq

Hilda Sabato

PRINCETON UNIVERSITY PRESS

PRINCETON छ OXFORD 
Copyright (C) 2018 by Princeton University Press

Published by Princeton University Press,

41 William Street, Princeton, New Jersey o8540

In the United Kingdom: Princeton University Press,

6 Oxford Street, Woodstock, Oxfordshire OX2o 1TR

press.princeton.edu

Jacket image: "South America." Lionel Pincus and Princess Firyal Map Division, The New York Public Library. New York Public Library Digital Collections.

All Rights Reserved

Library of Congress Control Number 2017954508

ISBN 978-0-691-16144-o

British Library Cataloging-in-Publication Data is available

This book has been composed in Miller

Printed on acid-free paper. $\infty$

Printed in the United States of America

$109876 \begin{array}{llllll} & 9 & 8 & 4 & 3 & 2\end{array}$ 
Para Julián y Andrés 
